\title{
Use of the polymerase chain reaction (PCR) to detect DNA from Renibacterium salmoninarum within individual salmonid eggs
}

\author{
L. L. Brown ${ }^{1,2, *}$, G. K. Iwama ${ }^{1}$, T. P. T. Evelyn ${ }^{2}$, W. S. Nelson ${ }^{3}$, R. P. Levine ${ }^{3}$ \\ ${ }^{1}$ Department of Animal Science, Canadian Bacterial Diseases Network, University of British Columbia, \\ \#248-2357 Main Mall, Vancouver, B.C., Canada V6T 1Z4 \\ ${ }^{2}$ Biological Sciences Branch, Department of Fisheries and Oceans, Pacific Biological Station, 3190 Hammond Bay Road, \\ Nanaimo, B.C., Canada V9R $5 \mathrm{~K} 6$ \\ ${ }^{3}$ Hopkins Marine Station, Stanford University, Oceanview Blvd, Pacific Grove, California 93950-3094, USA
}

\begin{abstract}
Renibacterium salmoninarum, the causative agent of bacterial kidney disease (BKD) in salmonids, can be transmitted vertically, i.e. from parent to progeny via the egg. The usual procedure to determine the likelihood of egg infection has been to examine non-egg tissues from mature female fish for evidence of $R$. salmoninarum cells or antigens. In the present study we examined the feasibility of detecting the pathogen directly within individual salmonid eggs by use of the polymerase chain reaction (PCR) to amplify segments of its DNA. Total DNA was extracted from the contents of eggs taken from several coho and chinook salmon (Oncorhynchus kisutch and O. tshawytscha), including coho eggs that had been injected with numbers of $R$. salmoninarum cells ranging from 2 to 2000 cells per egg. We also isolated DNA from kidney samples taken from these fish. Utilizing the PCR, two 24-base oligonucleotide primers were used to amplify a 501 base-pair region of the gene encoding a $57 \mathrm{kDa}$ soluble protein ('p57') produced by $R$. salmoninarum. A segment of DNA of the appropriate size (501 base-pairs) from $R$. salmoninarum was detected by the PCR in all of the injected eggs. $R$. salmoninarum DNA was also detected in some of the eggs taken from the coho and chinook samples that had previously been diagnosed as 'high-BKD' or 'negative-BKD' fish. Direct sequencing of the heatdenatured, double-stranded amplification product was carried out by dideoxy termination using T7 DNA polymerase and ${ }^{35} \mathrm{~S}$ labelling. There was $100 \%$ homology between the partial sequence obtained from the amplified DNA fragment and the sequence of the p57 gene. The DNA extracted from other bacterial fish pathogens did not yield a positive result. These results indicate that the PCR is able to detect as few as $2 R$. salmoninarum cells per egg and that it may be feasible as a broodstock screening technique specific for $R$. salmoninarum.
\end{abstract}

KEY WORDS: PCR · DNA · BKD detection - Salmon eggs · Bacterial disease - Broodstock screening

\section{INTRODUCTION}

Renibacterium salmoninarum, the causative agent of bacterial kidney disease (BKD) in salmonid fishes (Sanders \& Fryer 1980), can be transmitted from parent to progeny via eggs, (i.e. be vertically transmitted) (Evelyn et al. 1986). Fish culturists attempt to eliminate the vertical transmission of $R$. salmoninarum by dis-

- Please address correspondence to L.L.B. at her address in Nanaimo carding eggs from broodstock that prove to be carriers of the pathogen. Despite broodstock screening, however, BKD is still responsible for significant losses in farmed and enhanced salmonids (Evelyn 1988), perhaps because the screening methods fail to detect all carriers.

Currently, broodstock are screened for Renibacterium salmoninarum with the enzyme-linked immunosorbent assay (ELISA) or with the fluorescent antibody test (FAT) (Elliott et al. 1989), the procedures being applied to kidney, or less frequently, ovarian fluid 
samples rather than to the eggs. These procedures, however, sometimes lack specificity (discussed later) and they apparently lack the sensitivity required to detect very light infections even though such infections may result in vertical transmission of the pathogen (Lee \& Evelyn 1989, L. L. Brown unpubl. data). In addition, although the sensitivity of the foregoing immunodiagnostic tests might be significantly enhanced using enrichment techniques (see for example Lee \& Gordon 1987), the time required for enrichment (ca $35 \mathrm{~d}$ ) is unacceptably long.

These limitations of the immunodiagnostic techniques led us to investigate the polymerase chain reaction (PCR) as a means for directly screening salmonid eggs for Renibacterium salmoninarum. The PCR amplifies selected fragments of nucleic acid (Mullis et al. 1986), and it has been used to amplify genomic DNA from samples as small as a single sperm cell (Li et al. 1988). In this study we applied this very sensitive technique to amplify and detect the DNA of $R$. salmoninarum cells within individual coho salmon Oncorhynchus kisutch eggs, paying particular attention to the sensitivity and specificity of the technique.

\section{MATERIALS AND METHODS}

Bacteria. Two isolates of Renibacterium salmoninarum were used: (1) ATCC strain 33209; and (2) isolate Rs384 from the Pacific Biological Station, Department of Fisheries and Oceans Canada in Nanaimo, B.C. The Rs 384 isolate was grown at $15^{\circ} \mathrm{C}$ for $3 \mathrm{wk}$ on a selective medium (Austin et al. 1983, Daly \& Stevenson 1985) supplemented ( $3 \% \mathrm{v} / \mathrm{v})$ with a cell-free, filtersterilized supernatant of a previously grown broth culture of $R$. salmoninarum that had been harvested at log phase (Evelyn et al. 1990). The cells were aseptically scraped from the plates and then suspended in sterile $\mathrm{NaCl}(0.85 \% \mathrm{w} / \mathrm{v})$ to give an absorbance of 2.5 at $420 \mathrm{~nm}$ corresponding to ca $10^{8}$ cells $\mathrm{ml}^{-1}$. The ATCC strain was grown in shaken cultures of the broth form of KDM-2 (Evelyn 1977) at $18^{\circ} \mathrm{C}$ for 7 to $14 \mathrm{~d}$. Laboratory isolates of Aeromonas salmonicida and A. hydrophila (strains $76-30$ and 35, respectively), Vibrio anguillarum and $V$. ordalii (strains 82-438 and 74-48, respectively), and Yersinia ruckeri (strain C75199), from the Pacific Biological Station, were grown on Tryptic Soy Agar (Becton-Dickinson, Cockeysville, MD) at $15^{\circ} \mathrm{C}$ for 2 to $4 \mathrm{~d}$ after which they were scraped aseptically from the plates and suspended in sterile $0.85 \%(\mathrm{w} / \mathrm{v}) \mathrm{NaCl}$.

Eggs and fish tissues. Eggs were collected from mature coho salmon ( 300 to 400 eggs per fish) that had returned to spawn at Big Qualicum and Robertson Creek Salmon Enhancement Hatcheries (Qualicum and Port Alberni, B.C., respectively). Contents of each egg were removed aseptically with a sterile syringe and 22 gauge needle, and then stored in individual Eppendorf tubes at $-80^{\circ} \mathrm{C}$. In addition, 80 prefertilized, non-water-hardened eggs were taken from 1 Big Qualicum female coho salmon and distributed into 4 groups of 20 eggs each. Each egg was microinjected with $1 \mu$ l of a suspension of live Renibacterium salmoninarum cells (strain Rs384 as described above) (Brown et al. 1990). Groups 1 through 4 received 2, 20, 200 , and 2000 bacterial cells per egg, respectively, as determined by plate count. All eggs, injected or not, were maintained at $-80^{\circ} \mathrm{C}$ until DNA was extracted for the PCR. When collecting the eggs from the salmon, the entire kidneys were also removed aseptically and then homogenized ( $20 \% \mathrm{w} / \mathrm{v}$ ) in phosphate-buffered saline $\left(\mathrm{PBS} ; 0.8 \% \mathrm{w} / \mathrm{v} \mathrm{NaCl}, 7 \mathrm{mM} \mathrm{K} \mathrm{HPO}_{4}, 2.5 \mathrm{mM}\right.$ $\mathrm{KH}_{2} \mathrm{PO}_{4}, \mathrm{pH}$ 7.2) containing $0.05 \%$ v/v Tween 20 (PBS/T20). Aliquots $(1 \mathrm{ml})$ of the homogenized kidney were removed and sampled to assay for the presence of $R$. salmoninarum by the ELISA and FAT, and the remainder of the homogenized tissue was stored at $-80^{\circ} \mathrm{C}$ until DNA was extracted for the PCR. For additional DNA samples, chinook salmon Oncorhynchus tshawytscha eggs that had reached the eyed stage were obtained from the Carson National Fish Hatchery in Carson, Washington (U.S. Fish and Wildlife Service) and donated by Mr R. Pascho. These eggs were also stored at $-80^{\circ} \mathrm{C}$. The Carson eggs were taken from 2 groups of parent fish: the first was a pooled population of fertilized eggs derived from 5 females and 5 males that had been previously diagnosed as having 'negative/low $R$. salmoninarum infection levels' based on an ELISA and FAT examination of kidney and coelomic fluid; the second was a group of fertilized eggs derived from a single male and a single female, each of which had been diagnosed as having 'high $R$. salmoninarum infection levels' by the same methods (R. Pascho pers. comm.).

Detection of bacterial cells within salmonid tissue via the ELISA and FAT. The homogenized kidney tissue samples were assayed for the presence of Renibacterium salmoninarum by means of the ELISA and FAT. The ELISA was done according to the method of Pascho et al. (1991) using commercially available polyclonal antiserum raised in goats against $R$. salmoninarum (Kirkegaard \& Perry Laboratories, Inc., Gaithersburg, MD). All of the samples were tested in triplicate. An optical density (OD) value in the ELISA for any sample was considered to be positive if that value was higher than the positive threshold value established for salmonid kidney tissue by Meyers et al. (1993). Similarly, an OD value was considered negative if it fell below the negative threshold established by the same authors (Meyers et al. 1993). The negative 
control for the ELISA assays was a kidney tissue homogenate prepared in the same manner as described above. This kidney tissue was taken from a coho salmon from the Pacific Biological Station, Nanaimo. The OD values for the negative control fell below the threshold value for negative samples that was established by Meyers et al. (1993). The FAT was a modification of the method of Bullock et al. (1980) utilizing polyclonal antibodies against $R$. salmoninarum raised in rabbits and conjugated to fluorescein (Microtek Research \& Development Ltd, Victoria). The antiserum was diluted $1: 1000$ in PBS, and rhodamine $10.018 \%$ $w / v)$ was used as a background stain. Then $10 \mu l$ of each homogenized kidney sample was placed on a glass slide. The smear was then air-dried and heatfixed, and then flooded with the antiserum/rhodamine mixture. The slides were placed in a moist chamber and incubated in the dark at room temperature for $1 \mathrm{~h}$ after which they were gently rinsed with and then soaked in PBS for 5 to $10 \mathrm{~min}$. After this, the slides were blotted dry, and coverslips were mounted with a commercially available fluorescence assay mounting solution (Gibco/BRL, Gaithersburg, MD). The slides were examined with an epifluorescence microscope at a magnification of $1000 \times$ (100 fields per slide).

DNA extraction. We extracted DNA from individual suspensions of Renibacterium salmoninarum (ATCC strain 33209), Aeromonas salmonicida, A. hydrophila, Vibrio anguillarum, $V$. ordalii, and Yersinia ruckeri, and from the eggs and kidney tissue samples by a phenol/chloroform method (Sambrook et al. 1989). Aliquots of the homogenized kidney tissue (ca $100 \mu$ ), or the contents of single eggs, were homogenized in $1 \mathrm{ml}$ sterile STE buffer $(100 \mathrm{mM} \mathrm{NaCl}, 100 \mathrm{mM}$ EDTA, $50 \mathrm{mM}$ Tris- $\mathrm{HCl}, \mathrm{pH} 8.0$ ) and the nuclei lysed with $10 \mu \mathrm{l}$ of $20 \%$ sodium dodecyl sulfate. Proteins, lipids, and other contaminants were separated from the nucleic acids by 1 cycle each of phenol, phenol/chloroform, and chloroform extraction. The RNA was removed from the nucleic acids by digestion with $10 \mu \mathrm{l}$ per sample of a $10 \mathrm{mg} \mathrm{ml}^{-1}$ solution of RNase (Sigma, St. Louis, MO) at $37^{\circ} \mathrm{C}$ for 1 to $2 \mathrm{~h}$. After incubation, any residual contaminants were separated from the DNA by a second cycle of the organic extractions described above. The DNA was recovered by precipitation with absolute ethanol, washed with $70 \%$ ethanol, vacuum-dried, and finally redissolved in 50 to $75 \mathrm{Hl}$ TE buffer $(50 \mathrm{mM}$ Tris- $\mathrm{HCl} \mathrm{pH} 8.0,10 \mathrm{mM}$ EDTA). The concentration of DNA in each sample was determined spectrophotometrically at $260 \mathrm{~nm}$.

Primer synthesis. Two oligonucleotides (designated Rs1 and Rs2) were synthesized using an automatic synthesizer (Applied BioSystems Inc., Foster City, CA). Each primer contained 24 nucleotides chosen to amplify a 501 base-pair segment (codons 28 to 194 inclu- sive) of the gene that encodes a $57 \mathrm{kDa}$ extra-cellular protein produced by Renibacterium salmoninarum (Chien et al. 1992). The primer sequences of Rs1 and Rs2 are 5'-CAAGGTGAAGGGAATTCTTCCACT-3', and 5'-GACGGCAATGTCCGTTCCCGGTTT-3', respectively. The primers were chosen according to parameters outlined by Palumbi et al. (1991).

Polymerase chain reaction. Amplification was performed in $50 \mu \mathrm{l}$ of solutions containing $10 \mathrm{mM}$ Tris $\mathrm{pH}$ $8.3,50 \mathrm{mM} \mathrm{KCl}, 1.5 \mathrm{mM} \mathrm{MgCl}_{2}, 0.5 \mathrm{mM}$ of each dNTP (the nucleotide triphosphate of adenine, guanine, cytosine, and thymine), either 50 or 100 pmol of each primer, 2.5 units of DNA polymerase from Thermus aquaticus (AmpliTaq, Perkin Elmer Cetus, Norwalk, CT), and varying amounts of DNA as the template. The reaction mixtures were subjected to 30 amplification cycles $\left(94^{\circ} \mathrm{C}\right.$ denaturing for $1 \mathrm{~min}, 48^{\circ} \mathrm{C}$ annealing for $1 \mathrm{~min}$, and $72^{\circ} \mathrm{C}$ extending for $2 \mathrm{~min}$ ) in an automatic thermocycler (Perkin Elmer Cetus). These conditions were determined in a standard manner by varying buffer and $\mathrm{Mg}^{2+}$ concentrations, annealing and extension temperatures, to be the optimum for maximum amplification of the desired DNA fragment and minimization of secondary products. The amplified DNA was visualized by electrophoresis on a $2 \%(\mathrm{w} / \mathrm{v})$ agarose gel containing ethidium bromide, and the size compared to a $1 \mathrm{~kb}$ DNA ladder standard (Gibco/BRL).

Sequencing of the amplified DNA. For sequencing, the DNA fragments were separated from excess primers and unincorporated nucleotides with the use of the Magic PCR preparation purification system from Promega (Madison, WI). Direct sequencing of the heat-denatured, double-stranded amplification product was performed by dideoxy chain termination using T7 DNA polymerase and ${ }^{35} \mathrm{~S}$ labelling (Palumbi et al. 1991). The partial sequence generated was aligned with the published sequence (Chien et al. 1992) using the computer program Gene Works 2.1.1 (Intelligenetics, Mountain View, CA).

\section{RESULTS}

\section{Detection of bacterial cells within salmonid tissues via the ELISA and FAT}

Three of the four Big Qualicum coho salmon females examined were found to be negative for Renibacterium salmoninarum by ELISA and FAT examination of kidney tissues (Table 1). The Big Qualicum coho salmon female that served as a source of the eggs that were injected with $R$. salmoninarum was diagnosed as negative for the presence of the bacterium by the ELISA and FAT. All 6 of the Robertson Creek coho females were found to be positive by the ELISA, but 
Table 1. Salmonid tissues and eggs tested for the presence of Renibacterium salmoninarum by the polymerase chain. reaction (PCR), fluorescent antibody test (FAT), or enzyme-linked immunosorbent assay (ELISA). Results for the egg samples are expressed as: no. of eggs positive by PCR/no. of eggs sampled per fish

\begin{tabular}{|c|c|c|c|c|c|}
\hline \multirow{2}{*}{ Origin } & \multirow{2}{*}{ Fish no. } & \multicolumn{3}{|c|}{ Kidney } & \multirow{2}{*}{$\begin{array}{l}\text { Eggs } \\
\text { PCR }\end{array}$} \\
\hline & & PCR & FAT & ELISA & \\
\hline \multirow[t]{4}{*}{ B. $Q^{a}$} & 1 & + & - & - & $0 / 1$ \\
\hline & 2 & + & + & + & $3 / 3$ \\
\hline & 3 & + & - & - & $1 / 1$ \\
\hline & 4 & - & - & - & $1 / 2$ \\
\hline \multirow[t]{6}{*}{ R.C. ${ }^{b}$} & 1. & + & -4 & + & $0 / 15$ \\
\hline & 2 & - & $-{ }^{a}$ & + & $1 / 15$ \\
\hline & 3 & - & $-{ }^{d}$ & + & $0 / 14$ \\
\hline & 4 & - & $-{ }^{4}$ & + & $0 / 14$ \\
\hline & 5 & - & - & + & $0 / 13$ \\
\hline & 6 & - & - & + & $0 / 13$ \\
\hline \multirow[t]{2}{*}{ C.N.F.H. ${ }^{c}$} & 'Low' & Not done & - & - & $5 / 7$ \\
\hline & 'High' & Not done & + & + & $4 / 7$ \\
\hline
\end{tabular}

${ }^{\mathrm{a}}$ B.Q. = Big Qualicum Salmon Enhancement Hatchery, Department of Fisheries and Oceans, Qualicum, British Columbia. Tissues and eggs taken from coho salmon Oncorhynchus kisutch

${ }^{b}$ R.C. $=$ Robertson Creek Salmon Enhancement Hatchery, Department of Fisheries and Oceans, Port Alberni, B.C. Tissues and eggs taken from coho salmon

${ }^{c}$ C.N.F.H. = Carson National Fish Hatchery, U.S. Fish and Wildlife Service, Washington. Eggs taken from chinook salmon O. tshawytscha

dThese samples contained a large Gram-negative bacterium that yielded a positive FAT reaction, but no $R$. salmoninarum cells were detected

all were negative for $R$, salmoninarum by the FAT (Table 1). It should be noted, however, that fluorescing bacterial cells were observed in 4 of the 6 kidney samples from this fish stock (Robertson Creek fish nos. 1 to 4 , Table 1). However, the cells were too large (5 to $10 \mu \mathrm{m}$ long) to be considered $R$. salmoninarum (Sanders \& Fryer 1980). In addition, the typical fluorescence pattern associated with a positive reaction for R. salmoninarum cells (Bullock et al. 1980) was not observed. Therefore, these samples were judged to be negative for $R$. salmoninarum by the FAT.

\section{Polymerase chain reaction}

A fragment of the appropriate size (501 base-pairs) was amplified from DNA extracted from Renibacterium salmoninarum grown in culture (Fig. 1). The same size fragment was obtained from each of the eggs that had been injected with cells of $R$. salmoninarum (Fig. 2, Lanes 2 to $5 \& 7$ ); a total of 4 eggs from each group was assayed (complete data not shown). The

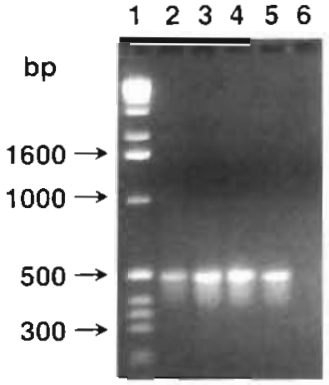

Fig. 1. Agarose gel electrophoresis of amplification products from varying concentrations of Renibacterium salmoninarum DNA and primers. Lane 1: molecular weight markers (basepairs, bp); Lane 2: $3.72 \mu \mathrm{g} \mathrm{ml}^{-1}$ template DNA and $50 \mathrm{pmol}$ of each primer; Lane 3: $3.72 \mu \mathrm{g} \mathrm{ml}^{-1}$ template DNA and 100 pmol of each primer; Lane 4:7.44 $\mathrm{g} \mathrm{mil}^{-1}$ template DNA and 50 pmol of each primer; Lane $5: 7.44 \mu \mathrm{g} \mathrm{mi}^{-2}$ template DNA and 100 pmol of each primer; Lane $6: R$. salmoninarum DNA omitted. All other reaction conditions as described in 'Materials and methods'

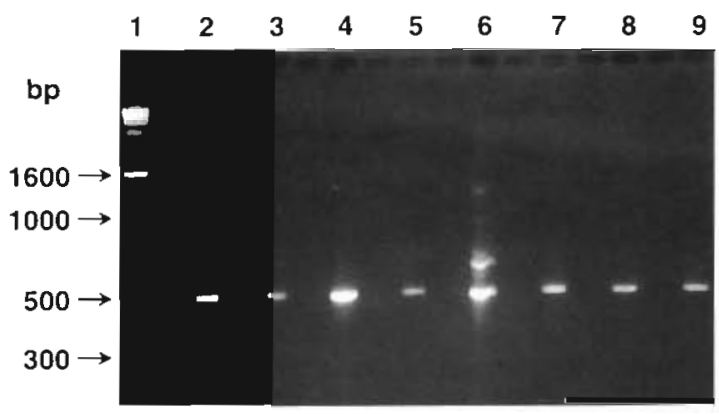

Fig. 2. Agarose gel electrophoresis of amplification products from DNA extracted from coho salmon Oncorhynchus kisutch eggs injected with Renibacterium salmoninarum cells and from uninjected eggs obtained from fish previously assayed for the presence of $R$. salmoninarum. Lane 1: molecular weight markers (base-pairs, bp); Lanes 2, 3, 4, 5 \& 7: DNA extracted from eggs injected with $R$. salmoninarum cells; Lane 2: egg injected with $2 R$. salmoninarum cells; Lane 3 : egg injected with $20 R$. salmoninarum cells; Lane 4: egg injected with $200 R$. salmoninarum cells; Lane 5: egg injected with $2000 R$. salmoninarum cells; Lane 6: Control DNA extracted from $R$. salmoninarum grown in culture; Lane 7: egg injected with $2 R$. salmoninarum cells; Lane 8: DNA extracted from an egg taken from a fish that had been diagnosed as positive for the presence of $R$. salmoninarum by ELISA and FAT; Lane 9: DNA extracted from an egg taken from a fish that had been diagnosed as negative for the presence of R. salmoninarum by ELISA and FAT. Al]. amplification reactions were carried out with $50 \mathrm{pmol}$ of each primer and amounts of template DNA varying from 4.48 to $8.36 \mu \mathrm{g} \mathrm{ml}^{-1}$ A.ll other conditions as described in 'Materials and methods'

other bacterial species tested (Aeromonas salmonicida, A. hydrophila, Vibrio anguillarum, V. ordalii, and Yersinia ruckeri) did not yield positive results, for no bands were detected upon electrophoresis (not shown).

Table 1 summarizes the results obtained with uninjected eggs and tissues from fish obtained from the Big 
Qualicum, Robertson Creek, and Carson National Fish Hatchery stocks. An amplification product of the expected size was obtained from 3 of the 4 DNA extractions from Big Qualicum coho salmon kidney tissues (fish nos. 1, 2, and 3). Two of those three (fish nos. 1 and 3) had been previously diagnosed as negative for the presence of Renibacterium salmoninarum by ELISA and FAT. Some of the eggs taken from fish nos. 2, 3 , and 4 were positive by PCR. Two of the positive eggs were taken from fish (nos. 3 and 4 ) that had been diagnosed as negative by ELISA and FAT (one of these 501 base-pair amplification products from fish no. 3 can be seen in Fig. 2, Lane 9). Of the Robertson Creek coho salmon females, 1 of the 6 DNA samples extracted from kidney tissue was positive by PCR (fish 1 ). A total of 84 eggs was examined, and a 501 base-pair amplification product was obtained from 1 egg taken from fish no. 2. Appropriate-sized amplification products were obtained in 5 of 7 of the DNA samples extracted from the 'low' Carson chinook salmon eggs. Four of the seven samples of eggs from the 'high' Carson fish were seen to yield the expected amplification products.

\section{Sequencing of amplified DNA}

The partial sequence (76 base-pairs) of the amplified DNA from an egg taken from Big Qualicum fish 3 (Table 1) was found to be $100 \%$ homologous with the sequence of the p57 gene (codons 28 to 194 inclusive) reported by Chien et al. (1992). This egg had not been injected with Renibacterium salmoninarum cells (Fig. 2, Lane 9).

\section{DISCUSSION}

The PCR is an effective diagnostic tool for detecting infectious agents of both vertebrates and invertebrates (Wernars et al. 1991, Kellner-Cousin et al. 1993), including salmonid pathogens (Gustafson et al, 1992). Whereas nucleic acid probes have been used to detect Renibacterium salmoninarum $16 \mathrm{~S}$ rRNA sequences (Mattsson et al. 1993), this is the first report of a successful DNA-based assay to detect $R$. salmoninarum within salmonid tissues. Moreover, the results presented here provide the basis for an assay that can be used to detect $R$. salmoninarum within salmonid eggs.

The method proved sufficiently sensitive to detect as few as 2 bacterial cells per egg (Fig. 2). It should be noted, however, that Renibacterium salmoninarum is auto-agglutinating (Bruno 1988) and that the sensitivity of the method was based on a statistical estimation of bacterial cell numbers from colony counts. Further, because the purpose of this study was to evaluate an assay procedure that was more sensitive in detecting the presence of $R$. salmoninarum within salmonid eggs than either the ELISA or the FAT, it was not possible to have a true negative control for this study. However, the injected eggs were obtained from a female coho salmon (Big Qualicum stock) that had been diagnosed as negative for the presence of $R$. salmoninarum. The parameters used to diagnose a negative fish by these methods were sufficiently stringent (Meyers et al. 1993) to assert that these fish were negative by the most sensitive methods available (i.e. the ELISA and FAT). Although we showed in this study that it was possible to obtain eggs that were positive for the presence of $R$. salmoninarum DNA from salmon that had been diagnosed as negative by the ELISA and FAT, we also showed that not all of the eggs obtained from those females were positive by the PCR (see Table 1). However, when we assayed the injected eggs for the presence of $R$. salmoninarum DNA, $100 \%$ of them were found to be positive, including the 4 eggs that had each been injected with as few as $2 R$. salmoninarum cells. It is unlikely that such consistent positive results would have been obtained if the $R$. salmoninarum DNA was from natural 'background' infections. This conclusion was supported by the fact that uninjected eggs, taken from the same stock of fish that underwent the same stringent assays for the presence of $R$. salmoninarum within their tissues, did not yield such consistently positive results. This was true whether the fish had been shown to be positive or negative for the presence of $R$. salmoninarum by the ELISA or FAT. Therefore, the DNA amplified from the injected positive control eggs was indeed derived from the bacterial cells injected, and the PCR as described here was sensitive enough to detect DNA from as few as 2 $R$. salmoninarum cells per egg.

All of the other bacterial pathogens of salmonids tested in this experiment yielded negative results by the PCR, implying that the primers Rs1 and Rs2 amplify a segment of genomic DNA specific to Renibacterium salmoninarum. Negative results obtained with some of the coho salmon tissues and eggs (Table 1) also confirmed the specificity of the PCR for detecting the presence of $R$. salmoninarum. If the primers Rs1 and Rs2 had in fact amplified a segment of salmonid rather than bacterial DNA within the eggs and tissues we would be have expected to detect an appropriatesized amplification product from all of the tissue and egg samples. Because this was not the case we are confident that the segment of DNA amplified was bacterial rather than salmonid.

As further evidence that direct examination of eggs for the presence of Renibacterium salmoninarum by the PCR is more effective than the indirect approaches 
hitherto used, we considered the results of the FAT examination of tissues from the Robertson Creek stock of coho salmon which contained an unidentified crossreacting bacterium. These results highlight the possibility of false-positive reactions using the immunodiagnostic approach and underline the importance of the highly specific PCR as an alternative for directly detecting $R$. salmoninarum within salmonid eggs. The fluorescein-conjugated polyclonal antibody used in the FAT has been known to react in fish tissues with bacterial species other than $R$. salmoninarum (Bullock et al. 1980, Austin \& Rayment 1985, Barbash 1992, Foott 1992). The bacterium (non- $R$. salmoninarum) in the Robertson Creek coho that fluoresced in the FAT as described above was isolated, and pure cultures were obtained on Tryptic Soy Agar, a medium that does not support the growth of $R$. salmoninarum (Evelyn et al. 1984). After subculturing the isolate 3 times, the unidentified Gram-negative bacterium was assayed by the FAT and ELISA, using the antiserum against $R$. salmoninarum as described above. Positive results were obtained in both assays (data not shown). In view of these observations, the positive results obtained by the ELISA in the assays on the kidney tissues from the Robertson Creek coho salmon stock may also be questionable. Finally, the sequence comparison confirmed the amplification of a 501 base-pair segment of the DNA that codes for the p57 gene of $R$. salmoninarum and proved that $R$. salmoninarum DNA was amplified. The PCR, as described and applied here, appeared to be specific and therefore may be more appropriate as a direct screening test for eggs than the ELISA and FAT.

As seen in Fig. 2, extra amplification products of approximately 700 and 1000 base-pairs in size were observed in DNA from Renibacterium salmoninarum grown in culture. These bands were not seen consistently, even when the same sample of DNA was used for amplification (for example, the control DNA in Fig. 2, Lane 6, is the same as that used in Fig. 1, Lanes $2,3,4 \& 5)$. One possible explanation is that nonspecific binding of the primers occurred in the repetitive regions described within the gene by Chien et al. (1992), and that much larger segments of the gene, encompassing these repetitive regions, were amplified along with the correct 501 base-pair segment. The erratic appearance of these bands did not detract from the reliability of the technique, however, as the 501 base-pair band was seen consistently in all of the positive controls and the injected eggs.

We conclude that the PCR has the potential to be a rapid (the total time required for the $\mathrm{PCR}$, including DNA extraction, is less than $48 \mathrm{~h}$ ), sensitive, and specific diagnostic technique for directly screening eggs for the presence of Renibacterium salmoninarum because every injected egg tested yielded a positive result (Fig. 2). Positive results were also obtained from eggs taken from fish that had been diagnosed as negative for the presence of $R$. salmoninarum by immunodiagnostic techniques (Fig. 2, Lane 9). If the PCR is to be applied to broodstock screening, a statistically significant number of eggs would have to be sampled from each spawning female. Whether to pool such a sample of eggs, and thus obtain a simple 'positive or negative' answer, or to examine them individually for a quantitative assessment of the egg infection prevalence is, in our opinion, a management question that must be based on the cost of the technique, the value of the stock, and the history of outbreaks of BKD within that stock.

Finally, although the PCR was studied for its potential as a diagnostic tool for detecting Renibacterium salmoninarum within salmonid eggs, the technique should also prove of value in studying the fate of the bacterium during the course of embryogenesis and in studies on the epizootiology of the pathogen.

Acknowledgements. The authors thank Mr I. R. Johnstone, Mr J. E. Ketcheson, and Mrs L. Prosperi-Porta for their technical assistance. Appreciation is also extended to Mr R. Pascho at the U.S. Fish and Wild]ife Service National Fisheries Research Center for supplying the samples of chinook salmon eggs. We are grateful to the personnel of the Canadian Department of Fisheries and Oceans Robertson Creek and Big Qualicum Salmon Enhancement Hatcheries for donating eggs and fish and for their field assistance. L.L.B. was supported by a Science Council of British Columbia Graduate Research and Engineering Training scholarship. This project was funded, in part, by operating grants to G.K.I. from the Natural Sciences and Engineering Research Council of Canada and the Canadian Bacterial Diseases Network National Centres of Excellence, and by U.S. Fish and Wildlife grants (\#14-48-0009-92-1297 and \#14-48-0009-92-1298) to R.P.L.

\section{LITERATURE CITED}

Austin, B., Embley, T M., Goodfellow, M. (1983). Selective isolation of Renibacterium salmoninarum. FEMS Microbiol. Lett. 17. 111-114

Austin, B., Rayment, J. (1985). Epizootiology of Renibacterium salmoninarum, the causal agent of bacterial kidney disease in salmonid fishes. J. Fish Dis. 8: 505-509

Barbash, P. A. (1992). Spore-forming bacteria isolated from fish feed found positive in direct fluorescent antibody test with Renibacterium salmoninarum antisera. Fish Health Section/Am. Fish. Sac. Newsl. 20(3): 5-6

Brown, L. L., Ricks, R., Evelyn, T. P. T., Albright, L. J. (1990) Experimental intra-ovum infection of coho salmon (Oncorhynchus kisutch) eggs with Renibacterium salmoninarum using a microinjection technique. Dis. aquat. Org. 8: 7-11

Bruno, D. W. (1988). The relationship between autoagglutination, cell surface hydrophobicity and virulence of the fish pathogen Renibacterium salmoninarum. FEMS Microbiol. Lett. 51: 135-140 
Bullock, G. L., Griffin, B. R., Stuckey, H. M., (1980). Detection of Corynebacterium salmoninus by direct fluorescent antibody test. Can. J. Fish. Aquat. Sci. 37.719-721

Chien, M. S., Gilbert, T. L., Huang, C., Landolt, M. L., O'Hara, P. J., Winton, J. R. (1992). Molecular cloning and sequence analysis of the gene coding for the $57-k D a$ major soluble antigen of the salmonid fish pathogen Renibacterium salmoninarum. FEMS Microbiol. Lett. 96: 259-266

Daly, J. G., Stevenson, R. M. W. (1985). Charcoal agar, a new growth medium for Renibacterium salmoninarum. Appl environ. Microbiol. 50: 868-871

Elliott, D. G., Pascho, R. J., Bullock, G. L. (1989). Developments in the control of bacterial kidney disease of salmonid fishes. Dis. aquat. Org. 6: 201-215

Evelyn, T P. T. (1977). An improved growth medium for the kidney disease bacterium and some notes on using the medium. Bull. off. Int. Epiz. 87: 511-513

Evelyn, T P. T. (1988). Bacterial kidney disease in British Columbia: comments on its epizootiology and on methods for its control on fish farms. In: AquaNor '87 International Conference. Norwegian Fish Farms Association and Sales Organization, Trondheim, p. 51-57

Evelyn, T P. T., Prosperi-Porta, L., Ketcheson, J. E. (1984). The salmonid egg as a vector of the kidney disease bacterium, Renibacterium salmoninarum. In: ACUIGRUP (ed.) Fish diseases, fourth COPRAQ session. EDITORA ATP, Madrid, p. 111-117

Evelyn, T P. T., Prosperi-Porta, L., Ketcheson, J. E. (1986). Experimental intra-ovum infection of salmonid eggs with Renibacterium salmoninarum and vertical transmission of the pathogen with such eggs despite their treatment with erythromycin. Dis. aquat. Org. 1: 197-202

Evelyn, T. P. T., Prosperi-Porta, L., Ketcheson, J. E. (1990). Two new techniques for obtaining consistent results when growing Renibacterium salmoninarum on KDM2 culture medium. Dis. aquat. Org. 9: 209-212

Foott, J. S., Starliper, C. E., Walker, R. L., Junell, D. (1992). Pseudomonas isolate gives positive direct fluorescent antibody test using Renibacterium salmoninarum antisera. Fish Health Section/Am. Fish. Soc. Newsl. 20(1): 2-3

Gustafson, C. E., Thomas, C. J., Trust, T. J. (1992), Detection of Aeromonas salmonicida from fish by using polymerase chain reaction amplification of the virulence surface array protein gene. Appl. environ. Microbiol. 58: $3816-3825$

Kellner-Cousin, K., Le Gall, G., Despres, B., Kaghad, M., Legoux, P., Shire, D., Mialhe, E. (1993). Genomic DNA cloning of rickettsia-like organisms (RLO) of Saint-Jacques scallop Pecten maximus: evaluation of prokaryote diagnosis by hybridization with a non-isotopically labelled probe

Editorial responsibility: Managing Editor and by polymerase chain reaction. Dis. aquat. Org. 15: $145-152$

Lee, E. G. H., Evelyn, T P. T (1989). Effect of Renibacterium salmoninarum levels in ovarian fluid of spawning chinook salmon on the prevalence of the pathogen in their eggs and progeny. Dis. aquat. Org. 7: 179-184

Lee, E. G. H., Gordon, M. R. (1987). Immunofluorescence screening of Renibacterium salmoninarum in the tissues and eggs of farmed chinook salmon spawners. Aquaculture $65: 7-14$

Li, H., Gyllensten, U. B., Cui, X., Saiki, R. K., Erlich, H. A., Arnheim, N. (1988). Amplification and analysis of DNA sequences in single human sperm and diploid cells. Nature 335: 414

Mattsson, J. G., Gersdorf, H., Jansson, E., Hongslo, T., Gobel, U. B., Johansson, K. E. (1993). Rapid identification of Renibacterium salmoninarum using an oligonucleotide probe complimentary to $16 \mathrm{~S}$ rRNA. Molec. cell. Probes 7: 25-33

Meyers, T R., Short, S., Farrington, C., Lipson, K., Geiger, H. J., Gates, R. (1993). Establishment of a negativepositive threshold optical density value for the enzymelinked immunosorbent assay (ELISA) to detect soluble antgien of Renibacterium salmoninarum in Alaskan Pacific salmon. Dis. aquat. Org. 16: 191-197

Mullis, K. B., Faloona, F. A., Schaarf, S. J., Saiki, R. K., Horn, G. T., Erlich, H. A. (1986). Specific enzymatic amplification of DNA in vitro: the polymerase chain reaction. Cold Spring Harbor Symp. quant. Biol. 51. 263

Palumbi, S. R., Martin, A., Romano, S., McMillan, W. O., Stice, L., Grabowski, G. (1991). 'A simple fool's guide to PCR'. Department of Zoology, University of Hawaii, Honolulu

Pascho, R. J., Elliott, D. G., Streufert, J. M. (1991). Brood stock segregation of spring chinook salmon Oncorhynchus tshawytscha by use of the enzyme-linked immunosorbent assay (ELISA) and the fluorescent antibody technique (FAT) affects the prevalence and levels of Renibacterium salmoninarum infection in progeny. Dis, aquat. Org. 12: $25-40$

Sambrook, J., Fritsch, E. F., Maniatis, T. (1989). Molecular cloning - a laboratory manual. Cold Spring Harbor Laboratory Press, Cold Spring Harbor, NY

Sanders, J. E., Fryer, J. L. (1980). Renibacterium salmoninarum gen.nov., sp.nov., the causative agent of bacterial kidney disease in salmonid fishes. Int. J. syst. Bact. 30 : $496-502$

Wernars, K., Delfgou, E., Soentoro, P. S., Notermans, S. (1991). Successful approach for detection of low numbers of enterotoxigenic Escherichia coli in minced meat by using the polymerase chain reaction. Appl. environ. Microbiol. 57-1914-1919

Manuscript first received: August 31, 1993

Revised version accepted: January 21, 1994 